\title{
The effect of Hegu acupoint stimulation in dental acupuncture analgesia
}

\author{
Fransiskus Andrianto*, Jenny Sunariani** and Theresia Indah Budhy $\mathbf{S}^{* * *}$ \\ * Student \\ ** Department of Oral Biology \\ Faculty of Dentistry, Airlangga University \\ Surabaya - Indonesia
}

\begin{abstract}
In daily life, dental treatments are often related with oral pain sensation which needs anesthesia procedures. Sometimes local anesthetics can not be used because patients have hypersensitive reaction or systemic diseases which may lead to complications. Stimulating acupoint, such as Hegu activates hypothalamus and pituitary gland to release endogenous opioid peptide substances that reduce pain sensitivity. The aim of the study was to determine Hegu acupoint stimulation effect on the pain sensitivity reduction in maxillary central incisor gingiva. The laboratory experimental research was conducted on 12 healthy male Wistar rats ( 3 months old, weights 150-200 grams). All rat samples received the same treatments and adapted within 1 month. The research was done in pre and post test control group design. 40-Volt electro-stimulation was done once on the maxillary central incisor gingiva prior to the bilateral Hegu acupoint stimulation, then followed by 3 times electro-stimulation with 3 minutes intervals. The pain scores were obtained based on the samples' contraction in each electro-stimulation. The responses were categorized into 5 pain scores and statistically analyzed using Wilcoxon Test. The results showed that Hegu acupoint stimulation lowered the pain scores significantly $(p<0.05)$. Hegu acupoint stimulation could reduce the pain sensitivity in maxillary central incisor gingiva. Therefore, the use of acupuncture analgesia in dental pain management can be considered in the future.
\end{abstract}

Key words: Hegu acupoint, Dental, Acupuncture analgesia

Correspondence: Theresia Indah Budhy S, c/o: Bagian Biologi Oral, Fakultas Kedokteran Gigi Universitas Airlangga. Jln. Mayjend. Prof. Dr. Moestopo 47 Surabaya 60132, Indonesia.

\section{INTRODUCTION}

In daily life, dental treatments are often related to oral pain sensation. Pain is a protective mechanism that occurs whenever any tissues are being damaged. Oral surgery treatments, such as tooth extraction needs anesthesia procedures to relieve the pain. In certain conditions, local anesthetics can not be used because patients suffered systemic diseases or hypersensitive reaction. ${ }^{1,2}$

Pain impulses are transmitted to the central nervous system (CNS) by two fibers system. One nociceptor system is made up of myelinated A fiber that secrete glutamate and transmit fast sharp pain. The other consists of unmyelinated $\mathrm{C}$ fibers that release substance $\mathrm{P}$ and glutamate. These latter fiobers transmit slow-chronic pain. Dental pulpal nociceptor system is made up of A fibers that secrete glutamate and transmit fast-sharp pain. Both fiber group end at the dorsal horn of the spinal pain. Both fibers groups end at the dorsal horn of the spinal cord. ${ }^{2-4}$ Pain impulses from oral cavity are transmitted to trigeminal nerves by mandible and maxillary nerves. ${ }^{5,6}$ Furthermore, these impulses are transmitted to CNS through somatic sensory pathway from spinothalamic tract at medula pons, and thalamus midbrain. Pain perception is processed at cerebral cortex to perceive pain location, intensity, and quality. ${ }^{7}$
Acupuncture is a traditional chinese medicine (TCM) that uses specific needles insertion in various certain acupuncture points (acupoints). Insertion of the needles in skin surface and muscle causes therapeutical effect and disease prevention. ${ }^{8}$ This technique can be used as an alternative in anesthesia procedure. ${ }^{9,10} \mathrm{Hegu}$ acupoint is often used in pain management because analgesia occurs by stimulating it. ${ }^{11}$

Hegu acupoint is a major point in large intestine meridian that has a pathway to orofacial area. ${ }^{12}$ Meridian is a specific pathway which interconnects acupoints to form a network with organs. Because of this specific relationship, meridian can be defined as specific cellular pathway. ${ }^{13}$ Stimulating acupoints results in Yin-Yang equilibrium by accelerating qi (bio-energy) flow. TCM's Yin-Yang equilibrium phenomena is in accordance with Western medicine's homeostasis. ${ }^{11,14,15}$ Acupuncture theory is based on cellular and molecular systems. Stimulus of bioenergy from acupoint is transmitted through both systems to target organ. ${ }^{13}$

Hegu acupoint is located between the first and the second metacarpal bones, approximately in the middle of the second metacarpal bone. Anatomically, this point passes through skin and subcutaneous tissues, penetrates musculus interosseous dorsalis I, and then reaches musculus 
adductor pollicis. ${ }^{16}$ Stimulating this acupoint with various levels of stimulation activates hypothalamus and pituitary gland to release endogenous opioid peptide substances ( $\beta$-endorphin, enkephalin, and dynorphin) that reduce pain sensitivity. $^{11}$

Based on the above background, the research was conducted to determine Hegu acupoint stimulation effect on the pain sensitivity reduction in maxillary central incisor gingiva. The research was conducted on male Wistar rats with medical bioenergy approach. By carrying out this research, anesthesia method using acupuncture is expected to be developed in dental science.

\section{MATERIALS AND METHODS}

The laboratory experimental research was done in pre and post test control group design. A total of 12 male Wistar rats were used in this research. All rats were healthy, 2-3 months old, weighed 150 to 200 grams, adapted within 1 month, and raised with same treatments.

All rats were fixated with band aid on the wooden fixation board at their chest, stomach, upper legs, and lower legs (Figure 2). Hegu acupoint (Figure 3) was located with acupuncture point detector Ying Di KWD-808-I, 6 channel output and 9 Volt DC Voltage (Figure 1), then marked with board marker. The marked points were smeared with cotton bud soaked in $75 \%$ alcohol.

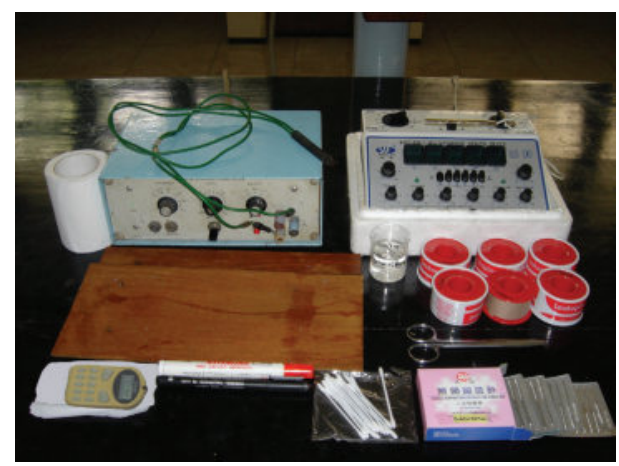

Figure 1. Electro stimulator, acupuncture point detector, wooden fixation board, bekker glass with $75 \%$ alcohol, band aid, stopwatch, board marker, cotton bud, scissors, acupuncture needles.

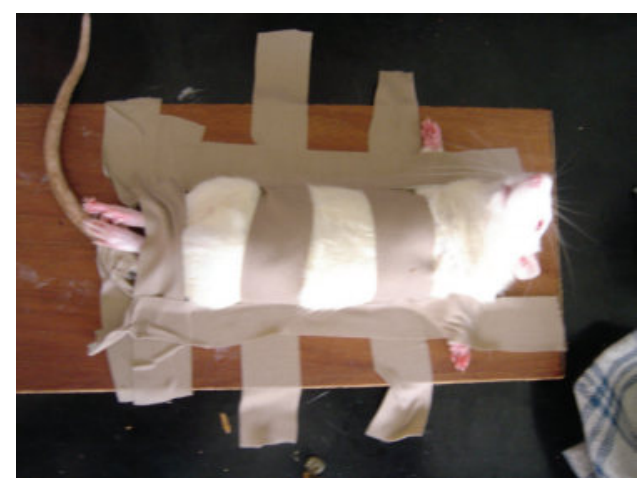

Figure 2. Rat fixated on wooden fixation board.

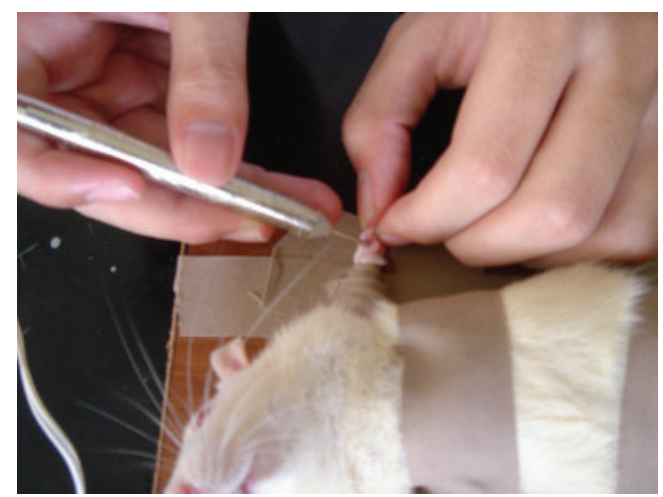

Figure 3. Hegu acupoint located with acupuncture point detector.

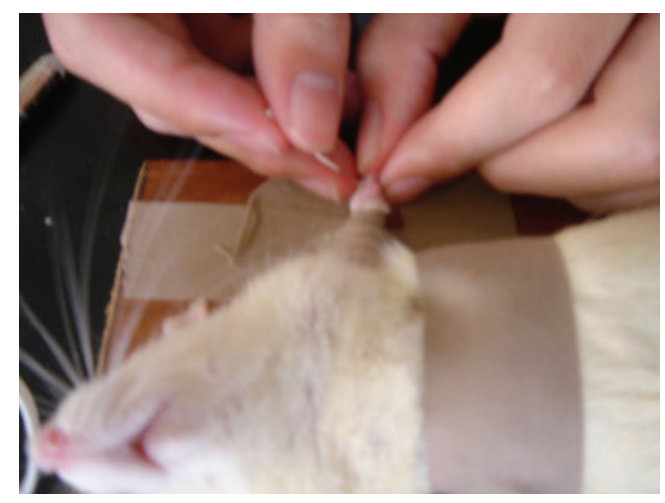

Figure 4. Needle insertion in Hegu acupoint.

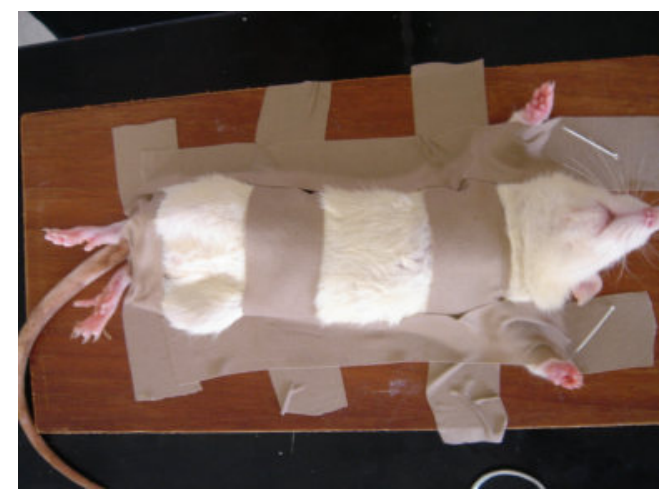

Figure 5. Rat with acupuncture needles inserted.

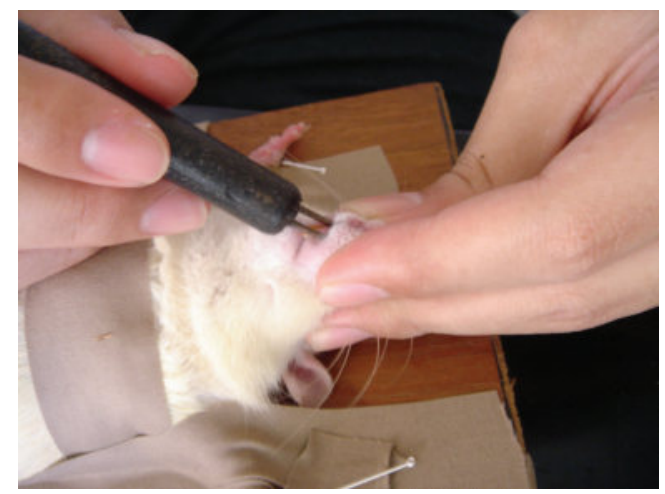

Figure 6. Electro-stimulation on maxillary central incisor gingiva with electro stimulator. 
All rats were once stimulated on maxillary central incisor gingiva with 40-Volt electro stimulator (Figure 6), then followed by bilateral needle insertion in $\mathrm{Hegu}$ acupoints with disposable stainless steel acupuncture needles $0.2 \mathrm{~mm}$ diameter and $13 \mathrm{~mm}$ long (Figure 5). The needles were manipulated by twirling approximately $90^{\circ}$ counter-clockwise twice. Electo-stimulations were done three times with 3 minutes intervals after $\mathrm{Hegu}$ acupoints stimulation. Pain scores obtained in each electro-stimulation were categorized into 5 scores based on contraction and extremities movement caused by spinal nerve stimulation. The pain scores were: ${ }^{17} 0=$ No surrounding tissues contraction and no extremities movement, $1=$ Local mucosa contraction, $2=$ Mucosa and lip contractions, $3=$ Mucosa and lip contractions, superior extremities movements, $4=$ Mucosa and lip contractions, superior and inferior extremities movements.

\section{RESULTS}

Pain scores at all rats were obtained by observation. The pain scores at the $3^{\text {rd }}$ minute, $6^{\text {th }}$ minute, and $9^{\text {th }}$ minute were obtained after Hegu acupoint stimulation (Table 1).

Table 1. Pain scores based on time intervals

\begin{tabular}{rcccc}
\hline & \multicolumn{5}{c}{ Scores } \\
\cline { 2 - 5 } No. & Initial & $3^{\text {rd }}$ minute & $6^{\text {th }}$ minute & $9^{\text {th }}$ minute \\
\hline 1 & 4 & 3 & 0 & 0 \\
2 & 4 & 4 & 3 & 2 \\
3 & 4 & 3 & 3 & 0 \\
4 & 3 & 3 & 3 & 2 \\
5 & 3 & 3 & 2 & 2 \\
6 & 3 & 3 & 2 & 0 \\
7 & 4 & 2 & 0 & 0 \\
8 & 4 & 2 & 2 & 2 \\
9 & 3 & 3 & 3 & 3 \\
10 & 3 & 3 & 3 & 2 \\
11 & 4 & 3 & 3 & 0 \\
12 & 4 & 3 & 3 & 3 \\
\hline
\end{tabular}

Based on above data, calculations were done to get Mean and Standard Deviation (Table 2). These calculation showed that pain scores decreased from the initial (initial $=$ $3.58)$, then the $3^{\text {rd }}$ minute $\left(\overline{\mathrm{X}} 3^{\text {rd }}{ }_{-}\right.$minute $\left.=2.92\right)$, the $6^{\text {th }}$ minute $\left(\overline{\mathrm{X}} 6^{\text {th }}-\right.$ minute $\left.=2.25\right)$, and the $9^{\text {th }}$ minute $\left(\overline{\mathrm{X}} 9^{\text {th }} \_\right.$minute $\left.=1.33\right)$.

Table 2. Mean and Standard Deviation of pain scores

\begin{tabular}{cccc}
\hline Time Group & Mean & Std. Deviation & $\mathrm{N}$ \\
\hline Initial_score & 3.58 & .515 & 12 \\
3_minute_score & 2.92 & .515 & 12 \\
6_minute_score & 2.25 & 1.138 & 12 \\
9_minute_score & 1.33 & 1.231 & 12 \\
\hline
\end{tabular}

The data calculated in Table 2 was statistically analyzed using Wilcoxon test to get the significance on differences of all time groups (Table 3 ).

Table 3. Wilcoxon test

\begin{tabular}{cccc}
\hline & 3_minute & 6_minute & 9_minute \\
& - Initial & - 3_minute & $-6 \_m i n u t e$ \\
\hline$Z$ & $-2.271^{\mathrm{a}}$ & $-2.060^{\mathrm{a}}$ & $-2.232^{\mathrm{a}}$ \\
Asymp. Sig. (2-tailed) & .023 & .039 & .026 \\
\hline
\end{tabular}

Wilcoxon test showed that there was a significant difference between $3^{\text {rd }}$ minute group and initial group $(\mathrm{p}=0.023, \mathrm{p}<0.05)$. There was a significant difference between $6^{\text {th }}$ minute group and $3^{\text {rd }}$ minute group $(\mathrm{p}=0.039$, $\mathrm{p}<0.05)$. Significant difference also occurred between $9^{\text {th }}$ minute group and $6^{\text {th }}$ minutes group $(p=0.026$, $p<0.05)$. These results mean that the pain scores decreased significantly from initial to the $9^{\text {th }}$ minute after $\mathrm{Hegu}$ acupoint stimulation.

\section{DISCUSSION}

Pain occurs whenever any tissues are being damaged, and it causes individual reacts to remove the pain stimulus. Pain can be elicited by multiple types of stimuli. They are classified as mechanical, thermal, chemical, and electrical pain stimuli. ${ }^{2-4}$ The pain receptors in the skin and other tissues are all free nerve endings. Pain stimuli on receptors cause sensitization and release of neurotransmitters. Some of the neurotransmitters that were excited are histamine, serotonin, bradykinin, prostaglandins, and leucotrien. Besides these chemicals, pain stimuli also cause the release of neuropeptide substance $\mathrm{P}$ that induce the release of histamine. $^{2-4,7}$

Pain is associated with behavioral response, motor reflexes, and alterations in autonomic output. ${ }^{18}$ The lateral and anterior corticospinal tracts are descending tracts that convey voluntary motor impulses from the brain (cerebrum) to spinal nerves at various levels in the cord. ${ }^{19}$ Rats' extremities movements in this research are based on the level of spinal nerves stimulation. ${ }^{17}$

Acupuncture technique used in this research was hand manipulated by twirling approximately $90^{\circ}$ counterclockwise twice. This technique is in accordance with TCM theory which is Xie, known as sedation and reduction method. Based on TCM theory, toothache is caused by heat accumulation from the intestine accompanied with pathogenic factor. Hegu acupoint is located in large intestine meridian so that sedation method reduced pathogenic $q i$ and heat accumulation. It is showed that the pain in rat's maxillary central incisor gingiva was relieved. ${ }^{20-22}$

In TCM, the natural world develops and constantly varies under the interaction of Yin and Yang. The philosophers and doctors in ancient China explained all the 
phenomena and the nature of the universe and life with the theory Yin-Yang. Ying and Yang are opposite to each other in nature, they constantly repel and restrain each other. If one side is weak and the other side is strong, the general equilibrium is not maintained. Thus, this abnormality will result in disorders, such as pain. Results in table 2 showed Mean of pain scores decrement from initial to $9^{\text {th }}$ minute after Hegu acupoint stimulation. The decrement occurred because there was an equilibrium between Yin and Yang by stimulating Hegu acupoint which is defined as homeostasis in western medicine. ${ }^{11,14,15,23}$

Acupoint stimulation induced bio-energy circulation through meridian to pain site. This stimulation also controlled the circulation physiologically. Bio-energy disruption in the form of excess energy is the cause of acute pain. ${ }^{24} \mathrm{Hegu}$ acupoint is located in large intestine meridian which has a pathway to orofacial. Hegu acupoint stimulation can reduce the pain by releasing the bio-energy obstruction at the area passed through meridian. The stimulation also relieved the pain by reducing pathogenic heat from large intestine pathway. ${ }^{22}$

Hegu acupoint stimulation activated hypothalamus and pituitary gland to release endogenous opioid peptide substances to periaqueductal gray matter (PAG) and nucleus raphe magnus (NRM). Thus, analgesia occurred because all pain impulses were inhibited at dorsal horn of the spinal cord. These endogenous opioid peptide substances inhibited the pain by opioid mechanism. ${ }^{25-29}$ Based on TCM, opiate receptor is categorized in Yin because of its opioidreceive characteristic, while endorphin and enkephalin are categorized in Yang because of their analgesic and therapeutic characteristic. Hegu acupoint stimulation resulted in equilibrium between Yin (opiate receptor) and Yang (endorphin and enkephalin) which reduced the pain sensitivity. ${ }^{30}$

Based on table 1, the most pain scores observed in initial group were 3 and 4 . This data showed that pain occurred in initial group was in high intensity before $\mathrm{Hegu}$ acupoint stimulation. Score 3 happened because pain impulses inhibition was inadequate so that impulses were transmitted to the brain and spinal nerves at the brachial plexus area (C5 to T1). The electro-stimulation resulted in motor muscles movement and the response was superior extremities movements. Score 4 was made based on superior extremities, inferior extremities, and tail flexion movements. These responses occurred because there was no inhibitory mechanism resulted in pain impulses transmission to brain and inferior spinal nerves at the sacral plexus (L5 to $\mathrm{S} 1$ ) and coccygeal plexus (S4 to Co1) area. ${ }^{19}$

Results showed that adequate analgesia occurred at $9^{\text {th }}$ minute. The pain scores in this group were mostly 2 and 0 . Score 0 occurred because pain impulses were inhibited by $\beta$-endorphin at peripheral afferent terminal with the result that the impulses could not be transmitted to nerve ending. Pain impulses transmitted to nerve ending were inadequate to induce stimulus at the area surrounding the nerve ending. Score 2 was the result of pain impulses transmitted to peripheral afferent terminal. The pain impulses transmission reached nerve VII through dorsal horn of the spinal cord. There was a lip contraction caused by nerve VII which innervates lip's motor muscles. Score 1 occurred because of inadequate pain impulses inhibition at peripheral afferent terminal. Thus, the impulses were transmitted to nerve VII without involving higher innervation system that caused local mucosa contraction. ${ }^{17,19}$

Some of the pain scores at the $9^{\text {th }}$ minute slightly decreased or did not decrease. The pain scores were both score 3 and 4 . These high scores might be caused by bio-energy flow deficiency or disorder in some rats which were anxious, stress, angry, and fearful. ${ }^{31}$ Bioenergy flow disorder caused imbalance between Yin and Yang, meridian function disorder, and disruption of bioenergy circulation. When acupuncture was done at Hegu acupoint, bio-energy flow did not circulate well. Thus, pain mechanism remained because obstruction or stagnation of bio-energy caused pain. ${ }^{14,24}$ High pain scores at the $9^{\text {th }}$ minute happened because endorphin secretion was not enough. Lack of endorphin resulted in pain because of inadequate analgesia.

Acupuncture analgesia needs a considerable amount of time to secrete enough endorphin. Some rats have opiate receptor deficiency and different ability to secrete endorphin. Inadequate analgesia could be happened to these rats. Electro-stimulation on stress rats showed high pain score because neurotransmitters were released at peripheral nerve end resulted in sensitization. Acupuncture analgesia also did not occur at rats which have pituitary suppression or ablation. ${ }^{25}$

Table 2 showed that Standard Deviation at both $6^{\text {th }}$ minute and $9^{\text {th }}$ minute were above 1 (SD6_minute $=1.138$ and SD9_minute $=1.231$ ). This condition might be caused by individual characteristic of rats which some of them showed excessive responses. Stress rats have higher pain sensitivity so that electro-stimulation could induce highest pain scores, while pain scores decrement in other rats occurred at these time groups. Therefore, this difference resulted in higher Standard Deviation compared to the other time groups.

The results concluded that $\mathrm{Heg} u$ acupoint stimulation could effectively reduce the pain sensitivity in maxillary central incisor gingiva. Clinical research can be conducted so that this research becomes applicable in dental science.

\section{REFERENCES}

1. Idayanti A. Akupunktur analgesia pada kasus pengobatan gigi. Meridian 1999; VI(3):128-32.

2. Guyton AC, Hall JE. Textbook of medical physiology. $11^{\text {th }}$ ed. Philadelphia: Elsevier Saunders; 2006. p. 57-71, 598-609.

3. Boron WF, Boulpaep EL. Medical physiology. Updated ed. Philadelphia: Elsevier Saunders; 2005. p. 172-203.

4. Ganong WF. Review of medical physiology. $22^{\text {nd }}$ ed. Singapore: McGraw-Hill Co. Inc; 2005. p. 51-64, 85-120, 142-7. 
5. Sunariani J, Mooduto L. Peran kortisol terhadap persepsi rasa nyeri pulpitis. Majalah Kedokteran Gigi (Dental Journal) 2002; 35(4):157-60.

6. Roth GI, Calmes R. Oral biology. St. Louis: The CV Mosby Co. 1981; p. 13-20.

7. Putra AD. Manajemen nyeri. Ethical Digest 2006; IV (26):70-2.

8. Wardani N. Akupunktur dalam bidang kedokteran gigi. Meridian 1994; I(2):122-34.

9. Saputra K. Akupunktur analgesia. Meridian 1997; IV(3):142-9.

10. Rosted P. Introduction to acupuncture in dentistry. Br Dent J 2000; 189(3):136-40

11. Saputra K. Akupunktur klinik. Surabaya: Airlangga University Press; 2002; p. 1-7, 71-5.

12. Wu HG, Luo DC. Modern chinese medicine. Vol. 2. Beijing: People's Medical Publ. House; 1984. p. 281, 555.

13. Adikara RTS. Profil keseimbangan (Taoisme) dalam era IPTEK modern untuk pembangunan bangsa Indonesia. Meridian 1995; II (2):118-23.

14. Wu CG, Zhu ZB. Basic Theory of traditional chinese medicine. Shanghai, China: Publishing House of Shanghai University of Traditional Chinese Medicine; 2000. p. 11-7, 102-9, 182-3, 194-209.

15. Saputra K. Akupunktur dalam pendekatan ilmu kedokteran. Surabaya: Airlangga University Press; 2000. p. 42-52.

16. Jing C. Anatomical atlas of chinese acupuncture points. China Shandong Science and Technology Press; 1990. p. 170, 184, 189.

17. Sunariani J, Soedarjanto H, Soetjipto H, Sari GM, Chusaida A. Pengaruh alkohol terhadap rasa nyeri pada tikus putih. Majalah Ilmiah Kedokteran Gigi Trisakti Desember 2000; 42:119-24.

18. Woolf CJ. Pain: Moving from symptom control toward mechanismspecific pharmacologic management. Ann Intern Med 2004; 140:441-51.

19. Solomon EP, Schmidt RR, Andragna PJ. Human anatomy and physiology. $2^{\text {nd }}$ ed. San Antonio: Saunders Coll. Publ; 1990. p. 124, 333-51, 462-70, 482-94, 654, 794.
20. Liu GW. Techniques of acupuncture and moxibustion. China: Huaxia Publ. House; 1998. p. 47, 54-7.

21. Pomeranz B, Stux G. Acupuncture textbook and atlas. Berlin: Springer-Verlag. 1987; p. 223-6.

22. Indian Gyan Home. Traditional chinese therapeutics. 2000. Available from URL: http://www. indiangyan.com/books/therapybooks/ clinical_acupunture/traditional_chinese_therapeutic.shtml. Accessed June 7, 2006.

23. San TC, Wangsasaputera E, Wiran S, Budi H, Kiswojo. Ilmu akupunktur. Edisi ke-2. Jakarta: Unit Akupunktur Rumah Sakit Dr. Cipto Mangunkusumo; 1985. p. 6-9.

24. Hendromartono. Akupunktur untuk nyeri kanker. Meridian 1997; IV(3):195-201.

25. Lee BY, LaRiccia PJ, Newberg AB. Acupuncture in theory and practice part I: Theoretical basis and physiologic effects. Hospital Physician 2004 April; 1:11-6.

26. Ahadian FM. Acupuncture in pain medicine: An integrated approach to the management of refractory pain. Current Pain and Headache Reports 2002; 6:444-51.

27. Filshie J, White A. Medical acupuncture: A western scientific approach. $5^{\text {th }}$ ed. London: Churchill Livingstone; 1998. p. 69-79.

28. Wu MT, Hsieh JC, Xiong J, Yang CF, Pan HB, Chen YCI, Tsai G, Rosen BR, Kwong KK. Central nervous pathway for acupuncture stimulation: Localization of processing with functional $\mathrm{mr}$ imaging of the brain-preliminary experience. Radiology 1999; 212:133-41.

29. Napadow V, Makris N, Liu J, Kettner NW, Kwong KK, Hui KKS. Effects of electroacupuncture versus manual acupuncture on the human brain as measured by fMRI. Human Brain Mapping 2005; 24:193-205.

30. Calehr H. Pedoman akupunktur medis. Jilid II. Jakarta: PT. Gramedia Pustaka Utama; 1993. p. 171-2.

31. Zijlstra FJ, Lange IVDB, Huygen FJPM, Klein J. Anti-inflammatory actions of acupuncture. Mediators of Infl 2003; 12(2):59-69. 